\title{
ERGENLIK DÖNEMINDE MUTLULUK VE UMUT ${ }^{1}$ \\ HAPPINESS AND HOPE IN ADOLESCENCE
}

\section{$\ddot{O} \mathbf{z}$}

\author{
Zeynep CIHANGIR ÇANKAYA ${ }^{2}$ - Betül MEYDAN ${ }^{3}$
}

Ergenlik dönemi gencin kişiliğinde ve yaşamının farklı boyutlarında birçok değişimin meydana geldiği önemli bir gelişim dönemidir. $\mathrm{Bu}$ dönemde yaşanan fiziksel ve psikolojik değiş̧imler ergenlerin mutluluk düzeylerini etkileyebilmektedir. Aynı zamanda bu dönemde umut, ergenler için önemli hale gelmektedir. İlgili yurtdışı alanyazında ergenlerin mutluluklarını etkileyen değişkenlerin ortaya çıkarılmasına ilişkin araştırmalar olduğu görülmektedir. Ancak Türkiye'de ergenlerin mutluluklarını etkileyen değişkenlerle ilgili yapılan çalışmalar sınırlıdır. $\mathrm{Bu}$ araştırmanın amacı, ergenlerin mutluluk düzeylerini bazı sosyodemografik değişkenlere göre incelemek ve ergenlerin mutluluk düzeylerini yordamada umut düzeylerinin rolünü belirlemektir. Araştırmanın çalışma grubunu 2015-2016 öğretim yılı bahar yarıyılında İzmir'de çeşitli liselerde öğrenim gören 506 lise öğrencisi oluşturmuştur. Araştırmada veriler Oxford Mutluluk Ölçeği, Sürekli Umut Ölçeği ve Demografik Bilgi Formu ile toplanmıştır. Verilerin analizinde betimsel istatistikler, bağımsız gruplar için $t$ testi, tek yönlü varyans analizi ve çoklu doğrusal regresyon analizi kullanılmıştır. Bulgular, cinsiyete, anne eğitim düzeyine ve baba eğitim düzeyine göre ergenlerin mutluluk düzeylerinin anlamlı düzeyde farklılaşmadığını göstermiştir. Bununla birlikte, umut değişkeninin ergenlerin mutluluk düzeylerinin anlamlı bir yordayıcısı olduğu bulunmuştur. Sürekli Umut Ölçeği'nin alt ölçekleri ergenlerin mutluluk düzeylerindeki toplam varyansın \%42'sini açıklamaktadır. Elde edilen sonuçlar ilgili alanyazın ışığında tartışılmış ve bazı öneriler sunulmuştur.

Anahtar Kelimeler: Ergenlik, ergen, mutluluk, umut, sosyodemografik değişkenler.

\begin{abstract}
Adolescence is an important developmental stage in which adolescents experience several changes regarding their personality and different dimensions of their lives. Physical and psychological changes in adolescence can affect happiness levels of adolescents. Also, hope becomes an important concept for adolescents in this developmental stage. In the international literature, there are several studies aiming at revealing variables which affect happiness of adolescents. However, there are limited studies that investigated variables which affect happiness of adolescents in Turkey. Therefore, the purpose of the present study was to examine happiness levels of adolescents according to some socio-demographic variables and to investigate the role of adolescents' hope levels in predicting their happiness levels. The study group consisted of 506 adolescents enrolled in various high schools in Izmir during spring semester of 2015-2016 academic year. The data were collected through Oxford Happiness Questionnaire, Dispositional Hope Scale, and Demographic Information Form. Descriptive statistics, independent samples t-test, one-way ANOVA, and multiple linear regression analysis were used to analyze the data. Findings showed that there were no significant difference among happiness levels of adolescents according to gender, education level of mothers, and education level of fathers. Nevertheless, it was found that adolescents' hope was a significant predictor of their happiness. Subscales of Dispositional Hope Scale explained $42 \%$ of the total variance of happiness scores of adolescents. These findings were discussed in the light of the relevant literature and recommendations were presented.
\end{abstract}

Keywords: Adolescence, adolescent, happiness, hope, socio-demographic variables.

\footnotetext{
${ }^{1} \mathrm{Bu}$ çalışma IV $V^{\text {th }}$ International Eurasian Educational Research Congress' de sözel bildiri olarak sunulmuştur.

${ }^{2}$ Doç. Dr., Ege Üniversitesi Eğitim Fakültesi Eğitim Bilimleri Bölümü Rehberlik ve Psikolojik Danışmanlık Anabilim Dalı, zeynepcihangircankaya@gmail.com

${ }^{3}$ Dr., Ege Üniversitesi Eğitim Fakültesi Eğitim Bilimleri Bölümü Rehberlik ve Psikolojik Danışmanlık Anabilim Dal1, betull_benzer@yahoo.com
} 


\section{GİRİŞ}

Ergenlik dönemi gencin kişiliğinin ve yaşamının farklı boyutlarında önemli değişimlerin yaşandığı bir gelişim dönemidir. Ergenler bu değişimlere uyum sağlama sürecinde, gelecekleri hakkında karar vermek, amaçlar belirlemek ve amaçlarına ulaşmak için uğraşmak durumundadır. Bu özellikleriyle ergenlik dönemi kaygı, stres ve depresyon gibi ruhsal sıkıntıların yaşanabildiği bir dönem olabildiği gibi (Andersen ve Teicher 2008; Davey, Yücel ve Allen, 2008), gençlerin olumlu bir kimlik geliştirdiği ve sağlıklı bir ruhsal yapı oluşturduğu (Park, 2004) bir dönem olarak da yaşanmaktadır. Ergenlik döneminin diğer gelişim dönemleri gibi, pozitif gelişimin ve stresin bir arada yaşandığı ve gencin bir kimlik inşa ettiği (Erikson, 1968) bir dönem olduğu söylenebilir. Bu kimlik oluşumu sürecinde ergenler, bir benlik algısı oluşturmakta, geçmişe ilişkin değerlendirmeler ve geleceğe ilişkin planlar yapmaktadır (Davey ve diğ., 2008). Bu gelişimsel süreçte çocukların ve ergenlerin yaşamlarını iyileştirmek amacıyla yapılan çalışmalar, psikopatolojiye, tedavi stratejilerinin geliştirilmesine ve risk önleme programlarının oluşturulmasına odaklanmaktadır (Park, 2004). Pozitif psikoloji akımının etkisiyle çocuk ve ergenleri mutsuz eden faktörlerin yerine mutluluklarını etkileyen faktörler üzerinde yapılan çalışmalarda artış olmuştur. Bu durum gelişim süreci içindeki sorunların, olumsuz durumların ve yetersizliklerin yanında pozitif özelliklerin de ele alınmasını sağladığı için, bireylerin psikolojik iyi oluşlarının tam bir resmini görmek mümkün olmaya başlamıştır (Diener, 1994). Bu bağlamda ülkemizde de ergenlerin pozitif yönlerine yani onların mutluluk, yaşam doyumu ve iyi oluş düzeylerini etkileyen faktörlere de odaklanmanın gerektiği düşünülmektedir.

\section{Mutluluk Modeli ve Ergenlik Döneminde Mutluluk}

Mutluluk iyi bir yaşamın yaygın olarak kabul edilen temel bileşenidir. Memnuniyet, yaşam doyumu, pozitif duygular ve yaşamda anlam sahibi olma gibi kavramları içinde barındırmaktadır. Günlük yaşamda mutluluk olarak adlandırılan durum alanyazında öznel iyi oluş olarak nitelendirilmekte, bazen de bu iki kavram birbirinin yerine kullanılmaktadır (Diener, Scollon ve Lucas, 2003; Park, 2004). Öznel iyi oluş modeli "mutluluğun hiyerarşik modeli" olarak ifade edilmekte (Diener ve diğ., 2003) ve bireyin yaşamının değerine ilişkin kararı olarak tanımlanmaktadır (Diener, 2000). Dolayısıyla, bireylerin kendi bakış açısını yansitmakta (Diener, Suh ve Oishi, 1997) ve mutluluğu, huzuru, memnuniyeti ve yaşam doyumunu (Diener, Oishi ve Lucas, 2003) içermektedir. Yaşam bütün olarak değerlendirildiğinde, yaşamdan alınan doyum öznel iyi oluş olarak ifade edilebilir. Bireylerin yaşamlarına ilişkin değerlendirmeleri ne kadar çok olumlu duygu ve düşüncelerle doluysa öznel iyi oluş düzeylerinin o kadar yüksek olacağı söylenebilir (Cihangir Çankaya, 2005).

Öznel iyi oluş modelinde (Diener ve diğ., 2003) olumlu duygulanım, olumsuz duygulanım, genel yaşam doyumu ve yaşam alanlarına ilişkin yaşam doyumu (iş, evlilik, sağlık gibi) olmak üzere dört temel boyut bulunmaktadır. Bu dört boyutlu modelde, bireylerin yaşamlarına ilişkin yaptıkları değerlendirmeler; temel olarak "bilişsel değerlendirme" (örneğin, yaşam doyumu, evlilik doyumu gibi) ve "yaşanan olumlu duygularla (örneğin, haz ve hoşlanma gibi) olumsuz duyguların (örneğin, üzüntü ve keder gibi) sıklığını ve yoğunluğunu belirleme" olarak iki alanda toplanmaktadır. Ayrıca bireylerin, bütün bir yaşamına ya da yaşamının bir alanına ilişkin bilinçli ve değerlendirici yargılarda bulunabileceği ifade edilmektedir (Diener ve diğ., 1997; Diener ve diğ., 2003). Öznel iyi oluş kapsamında yapılan yaşama ilişkin bilişsel değerlendirme, kavramın bilişsel alanını; mutluluk ya da iyi hissetme gibi olumlu duyguların varlığ1 ve öfke ya da kaygı gibi olumsuz duyguların yokluğu ise duygusal alanını (Argyle, 2001) oluşturmaktadır. Bu model çerçevesinde öznel iyi oluş düzeyi yüksek olan kişilerin, yaşam doyumu algısının yüksek olması, çoğunlukla olumlu duygular içinde olması ve nadiren üzüntü, keder, öfke gibi olumsuz duygular yaşaması beklenmektedir. Öznel iyi oluş düzeyi düşük olan 
kişilerin ise yaşamlarından doyum almaması, olumlu duygulardan çok öfke, tedirginlik, gerginlik, kaygı, depresyon gibi olumsuz duyguları yaşaması beklenmektedir (Lucas, Diener ve Suh, 1996; Diener ve di.̆., 1997).

Mutluluğun neden bu kadar önemli olduğunu ortaya koyan Diener (2000) tarafından 17 ülkeden üniversite öğrencileri üzerinde yapılan çalışmada, mutluluk ve yaşam doyumunun, kültürlerarası farklılıklara rağmen, tüm ülkelerde yaşayan gençler için gelir düzeyinden de öncelikli olacak şekilde çok önemli olduğu görülmüştür. Öznel iyi oluş ve mutlulukla ilgili yapılmış başka çalışmalar da mutluluk ve öznel iyi oluşun çeşitli davranışsal, psikolojik, sosyal ve kişisel pozitif sonuçların öncülü olduğunu göstermiştir (Demir ve Davidson, 2013; Garcia ve Archer, 2012; Lyubomirsky, King ve Diener, 2005, Padilla-Walker, Hardy ve Christensen, 2011; Richards ve diğ., 2015).

Ergenlik döneminde mutluluğa ilişkin yapılmış araştırmalar incelendiğinde de, son yıllarda çok sayıda çalışma olduğu dikkat çekmektedir (Chui ve Wong, 2016; Garcia ve Archer, 2012; Garcia ve Moradi, 2012; Gilman ve Huebner, 2006; Gray, Chamratrithirong, Pattaravanich ve Prasartkul, 2013; Padilla-Walker ve diğ., 2011; Proctor, Linley ve Maltby, 2009; Raboteg-Saric ve Sakic, 2014). Yapılan araştırmaların sonuçları da incelendiğinde, öncelikle öznel iyi oluşun ergenlerde de yetişkinlerde olduğu gibi çok boyutlu bir yapı olduğu görülmektedir (Huebner ve Dew, 1996; Long, Huebner, Wedell ve Hills, 2012). Yani mutlu bir ergenin, yaşamdan daha fazla doyum aldığı ve olumsuz duygulardan çok olumlu duygular yaşadığı düşünülmektedir (Garcia, Rosenberg, Erlandsson ve Siddiqui, 2010). Ergenlerin iyi oluş düzeylerini etkileyen faktörlere ilişkin çalışmalardan birinde ise (Chui ve Wong, 2016), öznel iyi oluşun ileri ergenlik döneminde azaldığı, anne babalarının evlilik durumlarının ve cinsiyetin ergenlerin iyi oluşları üzerinde anlamlı bir etki göstermediği, özsaygı, yaşamın anlamı, arkadaş sayısı değişkenlerinin ergenlerin iyi oluşları için anlamlı yordayıcılar olduğu bulunmuştur. Ayrıca 7-14 yaş arası çocuklarla yapılan çalışmada (Huebner, 1991) çocukların yaşam doyumlarının yaş, cinsiyet, sınıf değişkelerine göre farklılaşmadığı, yetişkinlerde olduğu gibi bireysel faktörlerin (içsel kontrol odağı, özsaygı, içsel motivasyon, dışa dönüklük) yaşam doyumları üzerinde çok daha fazla etkili olduğu bulunmuştur. Başka bir çalışmada (McCullough, Huebner ve Laughlin, 2000) büyük pozitif yaşam olayları kadar küçük pozitif yaşam olaylarının da gençleri yaşam doyumları üzerinde etkili olduğu, bir hobiyle ilgilenmenin, başkalarına yardım etmenin, arkadaşlarla sohbet etmenin gençlerin yaşam doyumlarının güçlü yordayıcıları olduğu görülmüş̧ür. Bir derleme çalışmasında da (Gilman ve Huebner, 2006), çocuk ve ergenlerin mutluluğunu açıklamada sosyodemografik değişkenlerin (yaş, sınıf, cinsiyet ve anne-baba eğitim düzeyi vb.) etkisinin, aynı yetişkin gruplarda olduğu gibi düşük olduğu görülmüştür. Ergenlerle ilgili yapılan bu çalışmalarda görüldügü gibi, ergen iyi oluş düzeylerinde sosyodemografik değişkenler zayıf bir etkiye sahipken; bireysel değişkenler önemli etki yaratmaktadır. Ülkemizde ergenler üzerinde yapılacak iyi oluş çalışmaları arttıkça, bizim kültürümüzde de benzer sonuçların olup olmadığı netleşebilecektir.

Bütün bunlara ek olarak, olumlu duygular yaşanmasına neden olan, mutlulukla ilgili psikolojik yapılardan birisinin de umut olduğu ortaya çıkmaktadır. Umut, ruh sağlığ problemlerine karşı koruyucu olan iyi oluşun pozitif bir yönü olarak ele alınmaktadır (Haroz ve diğ., 2015). Bernardo'nun (2015) belirttiği gibi araştırmacılar son 20 yıldır, çocuk ve ergenleri de içerecek şekilde bireylerin mutluluk ve umut düzeyleri arasındaki ilişkileri daha iyi anlamaya dönük çalışmalar yürütmektedir. Örneğin, Gilman ve Huebner (2006) tarafindan yaşam doyumu yüksek olan ergenlerin karakteristik özelliklerinin incelendiği bir araştırmada, söz konusu ergenlerin umut, özsaygı ve içsel kontrol odağı düzeylerinin yüksek olduğu bulunmuştur. Umutlu düşünce eğilimine sahip çocuk ve ergenlerin, yüksek özsaygıya ve yeterlik algısına, yaşam doyumuna sahip olduğunu gösteren çalışmalar bulunmaktadır 


\section{Umut Teorisi ve Ergenlik Döneminde Umut}

Umutla ilgili yapılan çalışmalarda, umudun çocuklar ve ergenlerin mutluluk düzeyleri için önemi açık bir biçimde ortaya çıkmıştır (Bernardo, 2015; Snyder, Lopez, Shorey, Rand ve Feldman, 2003). Umut, fiziksel ve ruhsal sağlığın farklı yönleri ile bağı olan ve olası olumsuz olaylara karşı tampon görevi gören pozitif psikolojik sağlı̆̆ın önemli bir boyutudur (PadillaWalker ve diğ., 2011). Çocuk ve gençlerle umut üzerine yapılan çalışmalar teorik olarak çoğunlukla Snyder'ın umut kuramını temel almaktadır (Bernardo, 2015). Umut kuramında (Snyder, 1994) ise umut, bireylerin kapasitelerine ilişkin algılarını yansıtan bilişsel ve motivasyonel bir yapı olarak ele alınmaktadır. Bu yapının "açık olarak kavramsallaştırılmış amaçlara sahip olma", "amaçlara ulaşmak için spesifik stratejiler geliştirme (pathways thinking)" ve "bu stratejileri kullanma ve sürdürme konusunda motivasyona sahip olma (agency thinking)" olmak üzere üç boyutu bulunmaktadır (Snyder, 2002). Belirlenen amaçların peşinden gitme motivasyonu (agency) ve amaca ulaşma yolları (pathways) umudu açıklamada önemli boyutlardır. Amaçların peşinden gitme/amaca güdülenme boyutu, amaca ulaşmayı isteme ve amaca ulaşmak için kendinde güç hissetme olarak tanımlanmakta ve "ben bunu yapabilirim düşüncesi”"ni yansıtmaktadır. Umudun bu boyutu, geçmiş, şu an ve gelecekteki amaçlara ulaşmak için belirlenen yolları uygulamaya yönelik inançları içerdiğinden, umut kuramının motivasyonel kısmıdır. Bu motivasyona sahip bireyler amaçları yönünde harekete geçebilirler, bunu sürdürebilirler, engelleyici durumlara karşı gelebilir ve onlarla baş edebilirler, bunlara ek olarak bu süreçte kendileriyle olumlu içsel konuşmalar yaparlar. Amaca ulaşma yolları boyutu ise; bireyin amaçlarına ulaşmak için plan yapma ve farklı yollar bulabilme konularında kendisine yönelik inançlarını içermektedir (Snyder, 2000; 2002; 2005).

Umut iyimserlik, özsaygı ve özyeterlik gibi bilişsel-motivasyonel kavramlardan farklı bir yapıdır. Örneğin; iyimserlik umutla benzerlik gösteren, istenilen sonuçların gerçekleşmesine ilişkin beklentileri ve istekleri içeren bilişsel bir süreç olmasıyla birlikte, Snyder umudun kritik yönünün, kişileri amaçlarına ulaştıracak ve sorunlara çözümler bulmalarını sağlayacak yollar geliştirmeleri olduğunu belirtmektedir (Scheier ve Carver, 1985; Snyder, 2002). Özyeterlik ve özsaygı da umut için gerekli yapılardır; ancak, umudu tam anlamıyla açıklamamaktadırlar (Padilla-Walker ve diğ., 2011). Özyeterlik, bireylerin öz-düzenleme, akademik ve empatik vb. yeterliklerine ilişkin inançlarına odaklanırken (Bandura, Caprara, Barbaranelli, Gerbino ve Pastorelli, 2003); umut, bireylerin çeşitli durum ve bağlamlardaki amaçlarına ve amaç odaklı düşüncelerine odaklanmaktadır. Özyeterlik umudun amaçların peşinden gitme motivasyonu (agency) boyutu ile yakın bir ilişki vermektedir (Magaletta ve Oliver, 1999). Özsaygı ise bireyin kendine ilişkin olumlu ve olumsuz değerlendirmelerini içermektedir. Bu haliyle özsaygının umudun duygusal kısmını içeren ve üçüncü boyutu olan "amaçların peşinden gitme" ile ilişkili olduğu söylenebilir (Padilla-Walker ve diğ., 2011).

Umutla ilgili yapılmış çalışmalar incelendiğinde, bu çalışmaların daha çok yetişkinlerle yürütüldüğü ve dolayısıyla umudun gelişimi ve ergenlerin davranışları ve öznel iyi oluş düzeyleriyle ilişkisine dair sınırlı bilgiler sağladığı görülmektedir (Padilla-Walker ve diğg., 2011; Parker ve diğ., 2015). Ergen gruplarıyla yürütülen çalışmalar yüksek umut düzeyine sahip olmanın sosyal yeterlikle (Barnum, Snyder, Rapoff, Mani ve Thompson, 1998) ve genel yaşam doyumuyla (Marques, Lopez ve Mitchell, 2013; Marques, Pais-Ribeirove ve Lopez, 2011; Valle, Huebner ve Suldo, 2004), öznel iyi oluşla (Kirmani, Sharma, Anas ve Sanam, 2015) olumlu bir ilişkisi olduğunu göstermiştir. Ergenlik döneminde umutsuzluğun ele alındığı bir çalışmada da, umutsuzluğun riskli davranışlar (saldırganlık, şiddet, cinsel davranışlar, saldırganlık ve şiddet içeren risk davranışlarının, yaralama vb.) için önemli bir yordayıcı olduğu bulunmuştur (Bolland, 2003). Benzer şekilde, bir başka araştırmada düşük umut düzeyine sahip ergenlerin, güvenli cinsel davranışlarının düşük olduğu ortaya çıkmıştır (Chang, Bendel, Koopman, McGarvey ve Canterbury, 2003). 
Türkiye'de ergenlerin mutluluk düzeylerini etkileyen değişkenlerle ilgili yapılan çalışmalar son yıllarda artış göstermekle beraber hala sınırlı sayıda olduğu söylenebilir. Ulaşılan bazı çalışmalarda, anne ve baba kabul ve ilgisinin, ailenin gelir düzeyinin (Özdemir, 2012), ilişkisel ve özerk benlik kurgularının (Özdemir, 2016), özyeterliğin (Telef ve Ergün, 2013), iyimserliğin ve özsaygının (Çivitci, 2010; Eryılmaz ve Atak, 2011), algılanan sosyal desteğin, anne baba eğitim düzeyinin (Çivitci, 2009; Ünal ve Şahin, 2013), ihtiyaç doyumunun ve yaşam amaçları belirlemenin (Eryılmaz, 2012a; 2012b) ergenlerin öznel iyi oluş düzeyleri üzerinde anlamlı etkileri olduğu; cinsiyetin (Özdemir, 2012, Ünal ve Şahin, 2013) ve yaşın (Ünal ve Şahin, 2013) anlamlı bir etkisi olmadığı görülmüştür. Bununla birlikte, bazı çalışmalarda (Çivitci, Çivitci ve Fiyakalı, 2009; Çivitci, 2009) anne-baba birlikteliğinin ve sınıfın ergenlerin öznel iyi oluş düzeyleri üzerinde anlamlı etkileri olduğu; ancak bazı çalışmalarda ise (Ünal ve Şahin, 2013) bu değişkenlerin anlamlı bir etkisi olmadığı bulunmuştur.

Sonuç olarak, Türkiye'de ergenlerin mutluluğunu nelerin etkilediğinin ortaya konulmasına ihtiyaç olduğu görülmektedir. Bu çalışmanın sonuçlarının ergenlerin pozitif özelliklerinin geliştirilmesine yönelik çalışmalara katkı sağlayacağı düşünülmektedir.

\section{Araştırmanın Amacı}

$\mathrm{Bu}$ araştırmanın amacı, ergenlerin mutluluk düzeylerini bazı sosyodemografik değişkenlere (cinsiyet, yaş, sınıf düzeyi, anne ve baba eğitim düzeyi, anne ve baba ilişki durumu, kardeş sahibi olma durumu) göre incelemek ve ergenlerin mutluluk düzeylerini yordamada bireyin yaşamındaki değişimlerle oluşan ve karakter özelliklerinden biri olarak ele alınan umudun rolünü belirlemektir.

\section{YÖNTEM}

\section{Araştırma Modeli}

$\mathrm{Bu}$ araştırmada, ergenlerin mutluluk düzeylerinin bazı sosyodemografik değişkenlere göre anlamlı düzeyde fark gösterip göstermediği ve umut düzeylerinin mutluluk düzeylerini yordayıp yordamadığı incelenmiştir. Bu amaçla araştırmada betimleyici tarama modeli ve ilişkisel tarama modeli kullanılmıştır (Fraenkel ve Wallen, 2005).

\section{Çalışma Grubu}

Araştırmada çalışma grubu oluşturulurken, İzmir ilinde farklı sosyoekonomik düzeylerdeki liselerden her sınıf düzeyinden öğrencinin çalışma grubunda yer almasına dikkat edilmiştir. $\mathrm{Bu}$ çerçevede araştırmanın çalışma grubunu 2015-2016 öğretim y1lı bahar yarıyılında İzmir'de çeşitli liselerde öğrenim gören 506 lise öğrencisi oluşturmuştur. Araştırmaya katılan öğrencilerin 308'i (\%60.9) kız, 196'sı (\%38.7) erkektir ve iki öğrenci cinsiyetini belirtmemiştir. Öğrencilerin yaşları 15 ile 19 arasında değişmektedir. Öğrencilerin \%21.9'u (111) dokuzuncu sinıf, \%35.6's1 (180) onuncu sinıf, \%23.3'ü (118) on birinci sinıf, $\% 6.1$ 'si (31) on ikinci sınıfa devam etmektedir ve 66 öğrenci sınıf düzeyini belirtmemiştir. Öğrencilerin \%98.6's1 (499) annelerinin ve \%96.6's1 (489) babalarının hayatta olduğunu ifade etmişlerdir. Öğrencilerin anne ve babalarının eğitim düzeyleri incelendiğinde, annelerin $\% 2$ 'sinin (10) hiç okula gitmediği; \%19.8'inin (100) ilkokul mezunu; \%10.1'inin (54) ortaokul mezunu; \%26.3'ünün (133) lise mezunu; \%37.4'ünün (189) yüksekokul veya üniversite mezunu olduğu ve \%4.5'inin (23) lisansüstü eğitim aldığı; babaların ise \%0.8'inin (4) hiç okula gitmediği; \%12.3'ünün (62) ilkokul mezunu; \%12.6'sının (64) ortaokul mezunu; \%19.4'ünün (98) lise mezunu; \%46.4'ünün (235) yüksekokul veya üniversite mezunu olduğu ve \%8.3'ünün (42) lisansüstü eğitim aldığ görülmüştür. Öğrencilerin \%86.6's1 (438) anne babasının birlikte olduğunu; \%10.9'u anne babasının ayrı olduğunu belirtmiştir ve 13 öğrenci anne babasının 
ilişki durumuyla ilgili bilgi vermemiştir. Öğrencilerin kardeş durumları incelendiğinde, \%80.6'sının (406) kardeşinin olduğu; \%18.2'sinin (92) kardeşi olmadığı görülmüştür ve 6 öğrenci kardeşi olup olmadığını belirtmemiştir.

\section{Veri Toplama Araçları}

Araştırmada veri toplama aracı olarak Oxford Mutluluk Ölçeği, Sürekli Umut Ölçeği ve Demografik Bilgi Formu kullanılmıştır. Veri toplama araçlarına ilişkin bilgiler aşağıda verilmiştir.

Oxford Mutluluk Ölçeği: Oxford Mutluluk Ölçeği, Hills ve Argyle (2002) tarafından bireylerin mutluluk düzeyini belirlemek için geliştirilip Doğan ve Sapmaz (2012) tarafindan Türkçe'ye uyarlanmıştır. Ölçek, yirmi dokuz maddeden oluşmaktadır. Her madde altılı Likert tipi bir derecelendirme ölçeği kullanılarak değerlendirilmektedir. Ölçüt bağıntılı geçerlilik için yapılan analiz sonucunda, Oxford Mutluluk Ölçeği ile iyimserliği değerlendiren diğer ölçme araçları arasında pozitif yönde anlamlı düzeyde ilişkiler bulunmuştur. Ölçeğin iç tutarlılık katsayısı .91, test yarılama yöntemiyle elde edilen güvenilirlik katsayısı .86 ve ölçeğin bileşik güvenilirliği ise .91 olarak saptanmıştır. Ölçekten elde edilecek en düşük puan 29 , en yüksek puan 174'tür. Ölçekten yüksek puan alınması bireyin mutluluk düzeyinin yüksek olduğunu göstermektedir. Ölçeğin bu araştırma örnekleminde toplam puan için iç tutarlık katsayısı .89 bulunmuştur.

Sürekli Umut Ölçeği: Snyder ve diğerleri (1991) tarafindan geliştirilen Sürekli Umut Ölçeği'nin Türkçe'ye uyarlama çalışması Tarhan ve Bacanlı (2015) tarafından yapılmıştır. Ölçek, on beş yaş ve üstündeki bireylerin umut düzeylerini belirlemeyi amaçlamaktadır. Ölçek, on iki maddeden oluşmaktadır. Her madde sekizli Likert tipi bir derecelendirme ölçeği kullanılarak değerlendirilmektedir. Ölçek, Alternatif Yollar Düşüncesi ve Eyleyici Düşünceler olmak üzere iki alt boyuttan ve umutla ilgisi olmayan dolgu maddelerden oluşmaktadır. Ölçüt bağıntılı geçerlilik için yapılan analizlerin sonucunda, ölçeğin Yaşam Doyumu Ölçeği ile korelasyonunun pozitif yönde; UCLA Yalnızlık Ölçeği, Sürekli Kaygı Ölçeği ve Beck Umutsuzluk Ölçeği ile korelasyonlarının negatif yönde ve anlamlı olduğu görülmüştür. Ölçeğin iç tutarlılık katsayıları Alternatif Yollar Düşüncesi alt boyutu için .78, Eyleyici Düşünceler alt boyutu için .81 ve ölçeğin toplamı için .86 olarak bulunmuştur. Alt boyutlardan alınabilecek en düşük puan 4, en yüksek puan 32'dir. Ölçeğin tamamından elde edilecek en düşük puan 8 , en yüksek puan 64'tür. Ölçekten alınan puanın yüksek olması, bireyin umut düzeyinin yüksek olduğunu göstermektedir. Ölçeğin Alternatif Yollar Düşüncesi alt boyutu için bu araştırma örnekleminde toplam puan için iç tutarlık katsayısı .76 ve Eyleyici Düşünceler alt boyutu için bu araştırma örnekleminde toplam puan için iç tutarlık katsayısı .76 bulunmuştur.

Demografik Bilgi Formu: Demografik bilgi formu, araştırmacılar tarafindan geliştirilmiştir. Araştırmaya katılan öğrencilerin sınıf düzeyi, yaş, cinsiyet, anne ve baba eğitim düzeyi, anne ve baba ilişki durumu ve kardeş sayısı ile ilgili sosyodemografik bilgileri araştırmada kullanılmak üzere demografik bilgi formu aracılığıyla toplanmıştır.

İşlem

Araştırmanın veri toplama araçları öğrencilere okul psikolojik danışmanı tarafından ders saatlerinde sınıf ortamında gruplar halinde uygulanmıştır. Uygulama öncesinde öğrencilere araştırmanın amacına ve ölçekleri nasıl yanıtlayacaklarına ilişkin bilgi verilmiştir. Uygulama yaklaşık bir ders saati (45-50 dakika) sürmüştür.

\section{Verilerin Analizi}

Araştırmada elde edilen veriler, SPSS 23 paket programı kullanılarak analiz edilmiştir. Veriler 709 lise öğrencisinden toplanmıştır. Analizlere başlamadan önce veri setindeki kayıp 
veriler incelenerek veri setinden çıkarılmıştır. Sonuç olarak, 506 lise öğrencisinden toplanan verilerle analizler gerçekleştirilmiştir. Verilerin analizinde betimsel istatistikler, bağımsız gruplar için $\mathrm{t}$ testi, tek yönlü varyans analizi ve çoklu doğrusal regresyon analizi kullanılmıştır. Bulgular .05 anlamlılık düzeyinde test edilmiştir.

\section{BULGULAR}

$\mathrm{Bu}$ bölümde öncelikle değişkenlere ilişkin betimleyici istatistikler sunulmuştur. Ardından, ön analizler, bağımsız gruplar için $t$ testi, tek yönlü varyans analizi ve çoklu doğrusal regresyon analizi ile elde edilen bulgular sunulmuştur.

\section{Mutluluk ve Umut Değişkenlerine İlişkin Betimleyici İstatistikler}

Ergenlerin mutluluk düzeylerinin bazı sosyodemografik değişkenlere göre anlamlı düzeyde fark gösterip göstermediğinin ve umut düzeylerinin mutluluk düzeylerini yordayıp yordamadığının incelenmesine geçmeden önce araştırmada ele alınan mutluluk ve umut değişkenlerine ilişkin betimleyici istatistikler Tablo 1'de sunulmuştur.

Tablo 1 Mutluluk ve Umut Değişkenlerine ilişkin Öğrencilerin Elde Ettikleri Puanların Betimleyici istatistikleri

\begin{tabular}{cccccc}
\hline & N & Minimum & Maksimum & Ortalama & $\begin{array}{c}\text { Standart } \\
\text { Sapma }\end{array}$ \\
\hline Mutluluk & 506 & 44.00 & 167.00 & 114.40 & 21.89 \\
\hline Umut & 506 & 8.00 & 64.00 & 50.28 & 9.10 \\
\hline $\begin{array}{c}\text { Sürekli Umut Ölçeği- Alternatif } \\
\text { Yollar Düşüncesi Alt Boyutu }\end{array}$ & 506 & 4.00 & 32.00 & 26.27 & 4.81 \\
\hline $\begin{array}{c}\text { Sürekli Umut Ölçeği- Eyleyici } \\
\text { Düşünceler Alt Boyutu }\end{array}$ & 506 & 4.00 & 32.00 & 24.01 & 5.12 \\
\hline
\end{tabular}

\section{Ergenlerin Mutluluk Düzeylerinin Bazı Sosyodemografik Değişkenlere Göre İncelenmesine Ait Bulgular}

Araştırmada ergenlerin mutluluk düzeylerinin demografik bilgi formu aracılığıyla elde edilen sınıf düzeyi, cinsiyet, anne ve baba eğitim düzeyi, anne ve baba ilişki durumu ve kardeş sahibi olup olmamaları ile ilgili sosyodemografik değişkenlere göre karşılaştırılması amaçlanmıştır. $\mathrm{Bu}$ amaç doğrultusunda ergenlerin mutluluk düzeylerinin cinsiyete ve kardeş sahibi olup olmamalarına göre anlamlı düzeyde fark gösterip göstermediğinin belirlenmesi için bağımsız gruplar için t testi kullanılması amaçlanmıştır. Ancak, kardeş sahibi olma değişkenine ilişkin katılımcı sayıları incelendiğinde, "kardeş sahibi olan" ergenlerin 408, "kardeş sahibi olmayan" ergenlerin 92 kişi olduğu görülmüştür. Dolayısıyla, kardeş sahibi olma değişkeni için her bir hücrede karşılaştırılacak olan katılımcı sayıları arasındaki fark çok olduğundan bağımsız gruplar için $\mathrm{t}$ testi kullanılması uygun olmayacağı sonucuna varılmıştır. Cinsiyet değişkenine ilişkin bağımsız gruplar için t testine geçmeden önce, analizin varsayımlarının karşılanıp karşılanmadığı incelenmiştir. Bunun için öncelikle araştırmanın örnekleminin normal dağılım gösterip göstermediğinin incelenmesi için basıklık ve çarpıklık değerleri ile kontrol edilmiştir. Alanyazında basıklık ve çarpıklık katsayılarının -2 ve +2 arasında değerler almasının kabul edilebilir olduğunu belirtilmektedir (George ve Mallery, 2010). Araştırma örnekleminden elde edilen basıklık ve çarpıklık değerlerinin kabul edilebilir sınırlar içerisinde olması üzerine ikinci 
varsayım olan varyansların homojenliği Levene testi ile incelenmiştir. Levene testi sonuçları cinsiyet için $(\mathrm{F}=0,03 ; \mathrm{p}>.05)$ olarak bulunmuştur. Bu sonuç cinsiyet değişkeni için varyansların homojen olduğunu göstermiştir. Varsayımların analizinin ardından, bağımsız gruplar için $\mathrm{t}$ testi yapılmıştır. Ergenlerin mutluluk düzeylerine ait puanlarının ortalamalarının, cinsiyete göre karşılaştırılması amacıyla yapılan bağımsız gruplar için t testi sonuçları Tablo 2'de verilmiştir.

Tablo 2 Cinsiyet Değişkenine Göre Bağımsız Gruplar İçin T Testi Sonuçları

\begin{tabular}{cccccccc}
\hline Değişken & Grup & $\mathbf{n}$ & $\overline{\mathbf{X}}$ & $\mathbf{S}$ & SD & $\mathbf{t}$ & $\mathbf{p}$ \\
\hline Mutluluk & Kız & 308 & 114.10 & 22.13 & & & .86 \\
Mutluluk & Erkek & 196 & 114.90 & 21.64 & 502 & 0.40 & \\
\hline
\end{tabular}

Tablo 2'de görüldüğü gibi, kız öğrencilerin mutluluk ölçeğinden aldıkları puanların ortalaması ile erkek öğrencilerin mutluluk ölçeğinden aldıkları puanların ortalamasının karşılaştırılması için yapılan bağımsız gruplar için t testi sonucunda, kız öğrencilerin mutluluk ölçeğinden aldıkları puanların ortalamasının ve erkek öğrencilerin puanlarının ortalamasından anlamlı düzeyde farklılaşmadığı bulunmuştur $(\mathrm{t}(502)=0.40 ; \mathrm{p}>.05)$.

Araştırmada ergenlerin mutluluk düzeylerinin sınıf düzeyi, anne ve baba eğitim düzeyi ve anne ve baba ilişki durumu ile ilgili sosyodemografik değişkenlere göre anlamlı düzeyde fark gösterip göstermediğinin belirlenmesi için tek yönlü varyans analizi kullanılması amaçlanmıştır. Tek yönlü varyans analizine geçmeden önce, analizin varsayımlarının karşılanıp karşılanmadığı incelenmiştir.Bunun için öncelikle araştırmanın örnekleminin normal dağılım gösterip göstermediğine basıklık ve çarpıklık değerleri ile bakılmıştır.Bu değerlerin beklenen sınırlar içerisinde (-2 ve +2 arasında) olması üzerine (George ve Mallery, 2010) ikinci varsayım olan varyansların homojenliği Levene testi ile incelenmiştir. Levene testi sonuçları sınıf düzeyi için $(\mathrm{F}=2.83 ; \mathrm{p}<.05)$ olarak bulunmuştur. Bu sonuç, sınıf düzeyi için varyansların homojen olmadığını gösterdiği için sınıf düzeyi değişkeni için tek yönlü varyans analizi yapılmamıştır. Bununla birlikte, anne ve baba ilişki durumu için her bir kategorideki katılımcı sayıları incelendiğinde, "evli ve aynı evde yaşayanların" 438 anne ve baba, "evli ve ayrı evlerde yaşayanların" 6 anne ve baba ve "boşanmış" olanların 43 anne ve baba olduğu görülmüştür. Bu durumda, anne ve baba ilişki durumu için her bir hücrede karşılaştırılacak olan katılımcı sayıları arasındaki fark çok olduğundan tek yönlü varyans analizinin kullanılmasının uygun olmayacağ 1 sonucuna varılmıştır. Anne eğitim düzeyi için her bir kategorideki katılımcı sayıları incelendiğinde ise "okul gitmemiş" olanların 10 kişi, "ilkokul mezunlarının" 100 kişi, "ortaokul mezunlarının" 51 kişi, "lise mezunlarının" 133 kişi, "yüksekokul veya üniversite mezunlarının" 189 ve "lisansüstü mezunlarının" 23 kişi olduğu görülmüştür. Baba eğitim düzeyi için ise her bir kategorideki katılımcı sayıları incelendiğinde, "okul gitmemiş" olanların 4 kişi, "ilkokul mezunlarının" 62 kişi, "ortaokul mezunlarının" 64 kişi, "lise mezunlarının" 98 kişi, "yüksekokul veya üniversite mezunlarının" 235 ve "lisansüstü mezunlarının" 42 kişi olduğu görülmüştür. Benzer şekilde, anne ve baba eğitim düzeyi için de her bir hücrede karşılaştırılacak olan katılımcı sayıları arasındaki fark çok olduğundan her iki değişken için de "okula gitmemiş" olanların ve "lisansüstü mezunlarının" analizden çıkarılmasına; kuramsal olarak "ilkokul mezunlarının" ve "ortaokul mezunlarını" ise analizden önce "ilköğretim mezunu" olarak birleştirilmesine dolayısıyla anne ve baba eğitim düzeyi için "ilköğretim mezunları, "lise mezunları" ve "üniversite mezunları" kategorileriyle tek yönlü varyans analizi yapılmasına karar verilmiştir. Levene testi sonuçları anne eğitim düzeyi için $(\mathrm{F}=0.48 ; \mathrm{p}>.05)$ ve baba eğitim düzeyi için $(\mathrm{F}=0.35 ; \mathrm{p}>.05)$ olarak bulunmuştur. Bu sonuçlar anne eğitim düzeyi ve baba eğitim düzeyi değişkenleri için varyansların homojen olduğunu göstermiş̧tir. Varsayımların analizinin ardından, tek yönlü varyans analizine geçilmiştir. Ergenlerin mutluluk düzeylerine ait 
puanlarının ortalamalarının, anne eğitim düzeyine ve baba eğitim düzeyine göre karşılaştırılması amacıyla yapılan tek yönlü varyans analizi sonuçları Tablo 3'te verilmiştir.

Tablo 3 Tek Yönlü Varyans Analizi Sonuçları

\begin{tabular}{|c|c|c|c|c|c|c|c|c|c|c|}
\hline Değişken & Faktör & $\mathbf{n}$ & $\bar{X}$ & $\mathbf{S}$ & $\begin{array}{l}\text { Varyansın } \\
\text { Kaynağı }\end{array}$ & KT & Sd & KO & $\mathbf{F}$ & p \\
\hline \multirow[t]{5}{*}{ Mutluluk } & $\begin{array}{l}\text { Anne eğitim } \\
\text { düzeyi }\end{array}$ & & & & & & & & & \\
\hline & $\begin{array}{l}\text { İlköğretim } \\
\text { mezunu }\end{array}$ & 151 & 114.36 & 22.44 & Gruplararası & 446.06 & 2 & 223.03 & .48 & .62 \\
\hline & Lise mezunu & 133 & 113.68 & 19.70 & Gruplariçi & 219197.26 & 470 & 466.38 & & \\
\hline & $\begin{array}{l}\text { Yüksekokul } \\
\text { veya } \\
\text { Üniversite } \\
\text { mezunu }\end{array}$ & 189 & 115.95 & 22.17 & & & & & & \\
\hline & Toplam & 473 & 114.80 & 21.57 & & 219643.32 & 472 & & & \\
\hline \multirow[t]{5}{*}{ Mutluluk } & $\begin{array}{l}\text { Baba eğitim } \\
\text { düzeyi }\end{array}$ & & & & & & & & & \\
\hline & $\begin{array}{l}\text { İlköğretim } \\
\text { mezunu }\end{array}$ & 126 & 113.26 & 22.36 & Gruplararası & 332.05 & 2 & 166.03 & .35 & .71 \\
\hline & Lise mezunu & 98 & 114.21 & 18.77 & Gruplariçi & 218226.54 & 456 & 478.57 & & \\
\hline & $\begin{array}{l}\text { Yüksekokul } \\
\text { veya } \\
\text { Üniversite } \\
\text { mezunu }\end{array}$ & 235 & 115.25 & 22.79 & & & 458 & & & \\
\hline & Toplam & 459 & 114.48 & 21.85 & & 218558.59 & & & & \\
\hline
\end{tabular}

Tablo 3'te görüldüğü gibi, anne eğitim düzeyine göre ergenlerin mutluluk ölçeğinden aldıkları puanları arasındaki farka ilişkin $F$ değerinin anlamlı olmadığ $\mathrm{F}_{(2,470)=0.48 ;} \mathrm{p}>.05$ ) görülmüştür. Aynı şekilde baba eğitim düzeyine göre ergenlerin mutluluk ölçeğinden aldıkları puanları arasındaki farka ilişkin $F$ değerinin anlamlı olmadığ $\left.\mathrm{F}_{(2,456)=0.35 ;} \mathrm{p}>.05\right)$ bulunmuştur.

\section{Ergenlerin Mutluluk Düzeylerini Yordamada Umut Düzeylerinin Rolünün Íncelenmesine Ait Bulgular}

Çoklu doğrusal regresyon analizine geçmeden önce analizin varsayımları olan normallik, çoklu doğrusal bağlantı, doğrusallık ve otokorelasyon olmaması kontrol edilmiştir. Mutluluk değişkeninin normal dağılım gösterip göstermediğinin belirlenmesi amacıyla basıklık ve çarpıklık katsayıları incelenmiştir. Bu incelemede mutluluk değişkeninin basıklık ve çarpıklık katsayılarının -2 ve +2 arasında olduğu; bir başka deyişle kabul edilebilir değerler aldığı görülmüştür (George ve Mallery, 2010). Bu durumda mutluluk değişkeninin normal bir dağılıma sahip olduğu sonucuna varılmıştır. Çoklu doğrusal bağlantı varsayımının test edilmesi amacıyla $1-\mathrm{R}^{2}$ değeri incelenmiştir. Bu değer (.57), tolerans değerinden (.53) büyük olduğu için çoklu doğrusal bağlantı sorunu olmadığı anlaşılmıştır (Leech, Barrett ve Morgan, 2008). Doğrusallığın kontrol edilmesi amaciyla scatterplot'lar incelenmiştir. Scatterplot'larda 
dörtgene yakın bir dağılım olduğu görülmüş ve doğrusallık varsayımının karşılandığı sonucuna varılmıştır. Oto-korelasyon varsayımını test etmek amacıyla Durbin-Watson değeri hesaplanmıştır. Durbin-Watson Kritik Değerler Tablosu'na göre bu değerin 1.5 ile 2.5 arasında olması gerekmektedir (Alpar, 1997). Hesaplanan değer 2.04 çıktığı için bu durum otokorelasyon olmadığını göstermiştir. Sonuç olarak, yapılan ön analizler sonrasında çoklu doğrusal regresyon analizinin varsayımlarının karşılandığı görülmüştür. Varsayımların analizinin ardından, çoklu doğrusal regresyon analizine geçilmiştir.

Araştırmada, Oxford Mutluluk Ölçeği toplam puanı, Sürekli Umut Ölçeği Alternatif Yollar Düşüncesi alt boyutu toplam puanı ve Eyleyici Düşünceler alt boyutu toplam puanı ele alınan değişkenlerdir. Bu değişkenlere ilişkin ortalama değerler ve standart sapma değerleri Tablo 4'te verilmiştir.

Tablo 4 Mutluluk ve Umut Değişkenlerine iliş̧kin Betimsel Istatistikler

\begin{tabular}{lll}
\hline & Ortalama & Standart Sapma \\
\hline Sürekli Umut Ölçeği-Alternatif Yollar Düşüncesi Alt Boyutu & 26.27 & 4.81 \\
\hline Sürekli Umut Ölçeği-Eyleyici Düşünceler Alt Boyutu & 24.01 & 5.12 \\
\hline Mutluluk & 114.40 & 21.89 \\
\hline
\end{tabular}

Tablo 4 incelendiğinde, çalışma grubundaki ergenler için Oxford Mutluluk Ölçeği puanları ortalamasının 114,40; Sürekli Umut Ölçeği Alternatif Yollar Düşüncesi alt boyutu için puanları ortalamasının 26,27 ve Eyleyici Düşünceler alt boyutu için puanları ortalamasının 24,01 olduğu görülmektedir.

Ergenlerin mutluluk düzeylerini yordamada umut düzeylerinin rolünün incelenmesi amacıyla yapılan çoklu doğrusal regresyon analizinin sonuçları Tablo 5 'te verilmiştir.

Tablo 5 Umut Düzeylerinin Ergenlerin Mutluluklarını Yordama Düzeyi

\begin{tabular}{lccccccc}
\hline Yordayıcı Değişken & $\mathbf{B}$ & Standart Hata B & $\boldsymbol{\beta}$ & $\mathbf{t}$ & $\mathbf{p}$ & Íkili r & Kısmi r \\
\hline Sabit & 43.16 & 4.22 & - & 10.22 & .000 & - & - \\
\hline Alternatif yollar düşüncesi & .42 & .21 & .09 & 1.98 & .04 & .07 & .09 \\
\hline Eyleyici düşünce & 2.51 & .20 & .59 & 12.76 & .000 & .43 & .49 \\
\hline $\mathrm{R}=.65$ & $\mathrm{R}^{2}=.43$ & Adjusted $\mathrm{R}^{2}=.42$ & $\mathrm{~F}_{(2,503)=187.218}$ & & $\mathrm{p}=.000$ & &
\end{tabular}

Tablo 5 incelendiğinde, ergenlerin mutluluk düzeylerini yordamada umut düzeylerinin rolünün incelenmesine yönelik kurulan regresyon modelinin anlamlı olduğu görülmüştür $\left(\mathrm{F}_{(2,503)}=187,218 \mathrm{p}=.000\right)$. Tablodaki t değerleri incelendiğinde, Alternatif Yollar Düşüncesi ve Eyleyici Düşünceler alt boyutları ile mutluluk puanları arasında pozitif yönde ve anlamlı bir ilişki olduğu görülmüştür. Bununla birlikte, Sürekli Umut Ölçeği’nin alt boyutlarının ergenlerin mutluluk puanlarındaki toplam varyansın \%42'sini açıkladıkları bulunmuştur $(\mathrm{p}<0.05)$. Bu açıklama oranının oldukça önemli bir açıklama düzeyine işaret ettiği söylenebilir (Cohen, 1988; akt. Leech, Barrett ve Morgan, 2008).Regresyon katsayılarının anlamlılığına ilişkin t testi sonuçları incelendiğinde, mutluluk değişkeninin yordanmasında en önemli katkının,eyleyici düşünceler alt boyutundan geldiği, bunu alternatif yollar düşüncesinin izlediği görülmektedir. 


\section{TARTIŞMA, SONUÇ VE ÖNERILER}

$\mathrm{Bu}$ araştırmada ergenlerin mutluluk düzeylerini bazı sosyodemografik değişkenlere göre incelemek ve ergenlerin mutluluk düzeylerini yordamada bireyin yaşamındaki değişimlerle oluşan ve karakter özelliklerinden biri olarak ele alınan umudun rolünü belirlemek amaçlanmıştır. Araştırmada ele alınan sosyodemografik değişkenlerin (cinsiyet, anne ve baba eğitim düzeyi) ergenlerin mutluluğu üzerinde fark yaratıp yaratmadığına dair bulguları incelendiğinde, ergenlerin mutluluk düzeylerinin cinsiyet ve anne-baba eğitim düzeyi değişkenlerine göre farklılaşmadığı görülmüştür. Mutluluk üzerinde yapılan çalışmalarda cinsiyeti de içeren sosyodemografik değişkenlerin öznel iyi oluşun zayıf bir yordayıcısı olduğu sonucuna ulaşılmıştır (Diener, Suh, Lucas ve Smith, 1999; Csikszentmihalyi ve Hunter, 2003). $\mathrm{Bu}$ bulgularla birlikte, erkek ergenlerin yaşam doyumu düzeylerin kız öğrencilere göre daha yüksek olduğuna işaret eden çalışmalar da bulunmaktadır (Goldbeck, Schmitz, Besier, Herschbach ve Henrich, 2007; Moksnes, Løhre ve Espnes, 2012; Moksnes ve Espnes, 2013). Türkiye'de üniversite öğrencileri üzerinde yapılan bir çalışmada cinsiyetin öznel iyi oluşun anlamlı bir yordayıcısı olmadığı; ancak sınıf değişkeninin anlamlı bir yordayıcı olduğu ve son sınıfların öznel iyi oluş düzeylerinin alt sınıflardan yüksek olduğu görülmüştür (Şahin, Aydın, Sarı, Kaya ve Pala, 2012). Ergenler ve çocuklarla yapılan çalışmalarda yaş, sınıf, cinsiyet ve sosyoekonomik durum gibi sosyodemografik değişkenlere odaklanan çalışmalarda tutarlı sonuçların olmadığı ifade edilmektedir (Chui ve Wong, 2016). Türkiye'de ergenler üzerinde yapılan bu çalışmada da benzer sonuçların elde edilmesi mutluluk üzerinde sosyodemografik değişkenlerin etkisinin zayıf olabileceğini göstermektedir. Araştırmada sınıf düzeyi, annebabanın ilişki durumu değişkenlerinin ergenlerin mutluluk düzeyleriyle ilişkisi, bulgular bölümünde açıklanan sebepler nedeniyle incelenememiştir. Türkiye'de ergenlerin mutluluk düzeyleri üzerinde yapılacak bundan sonraki çalışmalarda farklı sosyodemografik özelliklerin de incelenmesinin yararlı olacağı düşünülmektedir.

$\mathrm{Bu}$ araştırmada ergenlerin mutluluk düzeylerinin yordanmasında umudun anlamlı bir yordayıcı olması bulgusu, çocuk ve ergenlerin umut düzeylerinin mutluluk ve ilgili kavramlarla ilişskisini ortaya koyan çalışmaların sonuçlarıyla tutarlılık göstermektedir (Barnum ve diğ., 1998; Gilman ve Huebner, 2006; Marques ve diğ., 2011; Marques ve diğ., 2013; Tarhan ve Bacanlı, 2015, Valle ve diğ., 2004). Türkiye'de üniversite öğrencileriyle yapılan bir çalışmada da benzer sonuçlara ulaşılmıştır (Şahin ve diğ., 2012; Tarhan ve Bacanlı, 2015). Bu bulgular umudun amaçlara ulaşmak için alternatif yollar oluşturma (pathways) ve amaçların peşinden gitme (agency) boyutlarının, ergenlerin olumlu duyguları ve mutluluğu deneyimlemelerine katkı sağladığını ortaya koymaktadır. Ergenlerin gelişim dönemlerinin bir özelliği olarak gelecek kaygısı yaşadıkları bilinmektedir. Araştırmanın bulguları ergenlik döneminin özellikleri çerçevesinde tartışıldığında, umut düzeyi yüksek ergenlerin kendilerine kısa, orta ve uzun vadeli amaçlar belirleyerek, amaçlarına ulaşmak için harekete geçerek kaygılarıyla baş edebildikleri, kendilerini daha mutlu hissettikleri söylenebilir. Diğer açıdan bakıldığında da ergenlere umutlu düşünme becerileri kazandırıldığında ve onların umut düzeyleri yükseltildiğinde, kendilerini daha mutlu hissetmeleri mümkün olabilecektir. Umut ergenlerin yaşam olaylarının üstesinden gelme konusunda daha iyimser, daha motive ve planlı olmaları nedeniyle daha mutlu oldukları düşünülmektedir. Umudun, ergenlerin bir durumda yapılması gerekenleri yapmak konusunda kendilerine inanmalarını ve harekete geçmelerini içerdiğinden, olumlu sonuçlara ulaşmalarını ve dolayısıyla mutluluk düzeylerinin yükselmesini sağladığı düşünülmektedir.

Araştırmanın anlamlı sonuçlarından birisi de, ergenlerin mutluluk düzeylerinin yordanmasında amaçların peşinden gitme motivasyonunun daha yüksek katkısının olduğunu belirlenmesidir. Magaletta ve Oliver (1999) tarafından yapılan çalışmada da amaçların peşinden gitme motivasyonunun özyeterlikle ilişkili olduğu ve bu nedenle genel iyi oluş düzeyine özel 
ve ayrı bir katkı sağladığı sonucuna ulaşılmıştır. Ayrıca umudun bu boyutunun özsaygı ile yüksek ilişki göstermesi (Padilla-Walker ve diğer., 2011) ve özsaygının da yaşam doyumu ile olan güçlü ilişkisi (Moksnes ve Espnes, 2013) amaçların peşinden gitme motivasyonun mutluluk üzerinde daha güçlü bir yordayıcı olması sonucunu açıklamaktadır.

Özetle, umudun ergenlerin mutlulukları üzerindeki etkileri bu araştırmayla da desteklenmiştir. Bu araştırmanın mutluluk ve umut değişkenlerinin ergenlik dönemindeki bir grup üzerinde incelenmesinin Türkiye'deki sınırlı sayıdaki araştırmalara katkı getirdiği düşünülmektedir. Bundan sonraki çalışmalarda ergenlerin mutluluk düzeylerini etkileyebilecek farklı değişkenler üzerinde çalışılması, Türkiye' deki ergenlerin mutluluklarını etkileyen pozitif faktörlerin tam bir resmini görmemizi sağlayacaktır. Bu ve yapılacak yeni araştırmaların sonuçları, ergenlerin gelişimlerini desteklemeye odaklanan gençliğin pozitif gelişimi (positive youth development) (Lerner, Almerigi, Theokas ve Lerner, 2005) çerçevesinde değerlendirildiğinde, Türkiye'de ergenlerin gelişimlerini desteklemeye dönük programlar oluşturmaya zemin hazırlayacaktır. Bununla birlikte, araştırmanın uygulamaya yönelik çıktıları çerçevesinde, ergenlerin umutlu düşünme becerilerinin geliştirilmesi için müdahale programlarının uygulanmasının ve bireyle ve grupla psikolojik danışma hizmetleri çerçevesinde "umut" üzerine odaklanılmasının ergenlerin kendilerini daha mutlu hissetmelerine katkı sağlayacağı düşünülmektedir.

\section{KAYNAKÇA}

Alpar, R. (1997). Uygulamalı çok değişkenli istatistiksel yöntemlere giriş-I.Ankara: Bağırgan Yayımevi.

Andersen, S. L. ve Teicher, M. H. (2008).Stress, sensitive periods and maturational events in adolescent depression.Trends in Neurosciences, 31(4), 183-191.

ARGYLE, M. (2001).The psychology of happiness, Hove, United Kingdom: Routledge.

Bandura, A., Caprara, G. V., Barbaranelli, C., Gerbino, M. ve Pastorelli, C. (2003).Role of affective self- regulatory efficacy in diverse spheres of psychosocial functioning.Child Development, 74(3), 769-782.

Barnum, D. D., Snyder, C. R., Rapoff, M. A., Mani, M. M. ve Thopmson, R. (1998).Hope and social support in psychological adjustment of children who have survived burn injuries and their matched controls. Children's Health Care, 27(1), 15-30.

Bernardo, A. B. (2015). Hope in early adolescence: Measuring internal and external locus-ofhope.Child Indicators Research, 8(3), 699-715.

Bolland, J. (2003). Hopelessness and risk behavior among adolescents living in high poverty inner-city neighborhoods.Journal of Adolescence, 26, 145-158.

Chang, V. Y., Bendel, T. L., Koopman, C., McGarvey, E. L. ve Canterbury, R. J. (2003). Delinquents' safe sex attitudes relationships with demographics, resilience factors, and substance use.Criminal Justice and Behavior, 30(2), 210-229.

Chui, W. H. ve Wong, M. Y. (2016).Gender differences in happiness and life satisfaction among adolescents in Hong Kong: Relationship sand self-concept.Social Indicators Research, 125(3), 1035-1051.

Cihangir Çankaya, Z. (2005). Öz belirleme modeli: Özerklik desteği, ihtiyaç doyumu ve iyi olma. Yayınlanmamış Doktora Tezi, Ankara: Gazi Üniversitesi. 
Csikszentmihalyi, M. ve Hunter, J. (2003).Happiness in everyday life: The uses of experience sampling.Journal of Happiness Studies, 4, 185-199.

Çivitci, A. (2009). İlköğretim öğrencilerinde yaşam doyumu: Bazı kişisel ve ailesel özelliklerin rolü.Uludă̆ Üniversitesi Eğitim Fakültesi Dergisi, 22(1), 29-52.

Çivitci, A. (2010). Moderator role of self-esteem on the relationship between life satisfaction and depression in early adolescents.Emotional and Behavioural Difficulties, 15(2), 141152 .

Çivitci, N., Çivitci, A. ve Fiyakalı, C. (2009). Anne-babası boşanmış ve boşanmamış olan ergenlerde yalnızlık ve yaşam doyumu.Kuram ve Uygulamada Eğitim Bilimleri, 9(2), 493-525.

Davey, C. G., Yücel, M. ve Allen, N. B. (2008). The emergence of depression in adolescence: Development of the prefrontal cortex and the representation of reward.Neuroscience \& Biobehavioral Reviews, 32(1), 1-19.

Demir, M. ve Davidson, I. (2013). Toward a better understanding of the relationship between friendship and happiness: Perceived responses to capitalization attempts, feelings of mattering, and satisfaction of basic psychological needs in same-sex best friendships as predictors of happiness.Journal of Happiness Studies, 14(2), 525-550.

Diener, E. (1994). Assessing subjective well-being: Progress and opportunities. Social Indicators Research, 31(2), 103-157.

Diener, E. (2000). Subjective well-being. American Psychologist, 55(1), 34-39.

Diener, E.,Scollon, C. N. , ve Lucas, R. E. (2003). The evolving concept of subjective wellbeing: The multifaceted nature of happiness. Advances in Cell Aging and Gerontology, 15, 187-219.

Diener, E., Oishi, S. ve Lucas, R. E. (2003). Personality, culture, and subjective well-being: Emotional and cognitive evaluations of life.Annual Review of Psychology, 54(1), 403425 .

Diener, E., Suh, E. M., Lucas, R. E. ve Smith, H. L. (1999). Subjective well-being: Three decades of progress.Psychological Bulletin, 125, 276-302.

Diener, E., Suh, E. ve Oishi, S. (1997). Recent findings on subjective well-being.Indian Journal of Clinical Psychology, 24, 25-41.

Doğan, T. ve Sapmaz, F. (2012). Oxford Mutluluk Ölçeği Türkçe formunun psikometrik özelliklerinin üniversite öğrencilerinde incelenmesi.Düşünen Adam Psikiyatri ve Nörolojik Bilimler Dergisi, 25, 297-304.

Erikson, E. H. (1968). Identity, youth and crisis. New York: W. W. Norton Company.

Ery1lmaz, A. (2012a). A model for subjective well-being in adolescence: Need satisfaction and reasons for living.Social Indicators Research, 107(3), 561-574.

Ery1lmaz, A. (2012b). A model of subjective well-being for adolescents in high school.Journal of Happiness Studies, 13(2), 275-289.

Eryılmaz, A. ve Atak, H. (2011). Ergen öznel iyi oluşunun, öz saygı ve iyimserlik eğilimi ile ilişkisinin incelenmesi. Elektronik Sosyal Bilimler Dergisi, 37(37), 170-181.

Fraenkel, J. R. ve Wallen, N. E. (2005).How to design and evaluate research in education, New York: McGraw-Hill, Inc. 
Garcia, D. ve Archer, T. (2012). Adolescent life satisfaction and well-being.Journal of Alternative Medicine Research, 4(3), 271.

Garcia, D. ve Moradi, S. (2012). Adolescents' temperament and character: A longitudinal study on happiness.Journal of Happiness Studies, 13(5), 931-946.

Garcia, D., Rosenberg, P., Erlandsson A. veSiddiqui, A. (2010).On lions and adolescents: Affective temperaments and the influence of negative stimuli on memory.Journal of Happiness Studies, 11,477-495.

George, D. ve Mallery, M. (2010). SPSS for windows step by step: A simple guide and reference, 17.0 update. Boston: Pearson.

Gilman, R. ve Huebner, E. S. (2006).Characteristics of adolescents who report very high life satisfaction.Journal of Youth and Adolescence, 35, 311-319.

Goldbeck, L., Schmitz, T. G., Besier, T., Herschbach, P. ve Henrich, G. (2007). Life satisfaction decreases during adolescence. Quality of Life Research, 16, 969-979.

Gray, R. S., Chamratrithirong, A., Pattaravanich, U. ve Prasartkul, P. (2013).Happiness among adolescent students in Thailand: Family and non-family factors.Social Indicators Research, 110(2), 703-719.

Haroz, E. E., Jordans, M., Jong, J., Gross, A., Bass, J. ve Tol, W. (2015).Measuring hope among children affected by armed conflict cross-cultural construct validity of the Children's Hope Scale. Assessment, 24, 528-539.

Hills, P. ve Argyle, M. (2002).The Oxford Happiness Questionnaire: A compact scale for the measurement of psychological well-being.Personality and Individual Differences, 33(7),1073-1082.

Huebner, E. S. (1991). Initial development of the Student's Life Satisfaction Scale.School Psychology International, 12, 31-40.

Huebner, E. S. ve Dew, T. (1996). The interrelationships of positive affect, negative affect, and life satisfaction in an adolescent sample.Social Indicators Research, 38, 129-137.

Kirmani, M. N., Sharma, P., Anas, M. ve Sanam, R. (2015).Hope, resilience and subjective well-being among college going adolescent girls.International Journal of Humanities \& Social Science Studies, 2(1), 262-270.

Leech, N. L., Barrett, K. C. ve Morgan, G. A. (2008). Spss for intermediate statistics: Use and interpretation.Psychology Press.

Lerner, R. M., Almerigi, J. B., Theokas, C. ve Lerner, J. V. (2005). Positive youth development a view of the issues. The Journal of Early Adolescence, 25(1), 10-16.

Long, R. F., Huebner, E. S., Wedell, D. H. ve Hills, K. J. (2012).Measuring school-related subjective well-being in adolescents.American Journal of Orthopsychiatry, 82(1), 5060.

Lucas, R. E., Diener, E. ve Suh, E. (1996). Discriminant validity of well-being measures.Journal of Personality and Social Psychology, 71(3), 616-628.

Lyubomirsky, S., King, L. ve Diener, E. (2005).The benefits of frequent positive affect: Does happiness lead to success?.Psychological Bulletin, 131, 803-855.

Magaletta, P. R. ve Oliver, J. M. (1999).The hope construct, will and ways: their relations with self-efficacy,optimism, and general well-being.Journal of Clinical Psychology, 55(5), $539-551$. 
Marques, S. C., Lopez, S. J. ve Mitchell, J. (2013).The role of hope, spirituality and religious practice in adolescents' life satisfaction: Longitudinal findings.Journal of Happiness Studies, 14(1), 251-261.

Marques, S. C., Pais-Ribeiro, J. L. ve Lopez, S. J. (2011).The role of positive psychology constructs in predicting mental health and academic achievement in children and adolescents: A two-year longitudinal study.Journal of Happiness Studies, 12(6), 10491062.

McCullough, G., Huebner, E. S. ve Laughlin, J. E. (2000).Life events, self-concept, and adolescents positivesubjective well-being. Psychology in the Schools, 37, 1-10.

Moksnes, U. K. ve Espnes, G. A. (2013). Self-esteem and life satisfaction in adolescents-gender and age as potential moderators. Quality of Life Research, 22(10), 2921-2928.

Moksnes, U. K., Løhre, A. ve Espnes, G. A. (2012). The association between sense of coherence and life satisfaction in adolescents. Quality of Life Research, 22(6), 1331-1338.

Özdemir, Y. (2012). Examining the subjective well-being of adolescents in terms of demographic variables, parental control, and parental warmth.Education \& Science/Egitim ve Bilim, 37(165), 20-33.

Özdemir, Y. (2016). Ergenlerin öznel iyi oluşlarının özerk, ilişkisel ve özerk-ilişkisel benlik kurguları açısından incelenmesi.Türk Psikolojik Danışma ve Rehberlik Dergisi, 4(38), 188-198.

Padilla-Walker, L. M., Hardy, S. A. veChristensen, K. J. (2011).Adolescent hope as a mediator between parent-child connectedness and adolescent outcomes.Journal of Early Adolescence, 31(6), 853-879.

Park, N. (2004). The role of subjective well-being in positive youth development.The Annuals of the American Academy of Political and Social Science, 591(1), 25-39.

Parker, P. D.,Ciarrochi, J., Heaven, P., Marshall, S., Sahdra, B. ve Kiuru, N. (2015). Hope, friends, and subjective well- being: A social network approach to peer group contextual effects.Child Development, 86(2), 642-650.

Proctor, C. L., Linley, P. A. ve Maltby, J. (2009). Youth life satisfaction: A review of the literature.Journal of Happiness Studies, 10, 583-630.

Raboteg-Saric, Z. ve Sakic, M. (2014).Relations of parenting styles and friendship quality to self-esteem, life satisfaction and happiness in adolescents.Applied Research in Quality of Life, 9(3), 749-765.

Richards, J., Jiang, X., Kelly, P., Chau, J., Bauman, A. veDing, D. (2015).Don't worry, be happy: Cross-sectional associations between physical activity and happiness in 15 European countries. BMC Public Health, 15(1), 53.

Scheier, M. F. ve Carver, C. S. (1985).Optimism, coping, and health: Assessment and implications of generalized outcome expectancies. Health Psychology, 4, 219-247.

Snyder, C. R. (1994). The psychology of hope: You can get there from here. New York, NY: Free Press.

Snyder, C. R. (2000). Hypothesis: There is hope. Içinde C. R. Snyder (Ed.), Handbook of hope: Theory, measures, and applications(s. 3-21). San Diego, CA: Academic Press.

Snyder, C. R. (2002). Hope theory: Rainbows in the mind.Psychological Inquiry, 13(4), 249275. 
Snyder, C. R. (2005). Measuring hope in children. Içinde K. A. Moore \& L. H. Lippman (Ed.), What do children need to flourish? Conceptualizing and measuring indicators of positive development (s. 61-73). New York, NY: Springer.

Snyder, C. R., Harris, C., Anderson, J. R., Holleran, S. A., Irving, L. M., Sigmon, S. T., Yoshinobu, L., Gibb, J., Langelle, C. ve Harney, P. (1991). The will and ways: Development and validation of an individual-differences measure of hope. Journal of Personality and Social Psychology, 60(4), 570-585.

Snyder, C. R., Lopez, S. J., Shorey, H. S., Rand, K. L. ve Feldman, D. B. (2003). Hope theory, measurements, and applications to school psychology.School Psychology Quarterly, $18(2), 122-139$.

Şahin, M., Aydın, B., Sarı, S. V., Kaya, S. ve Pala, H. (2012). Öznel iyi oluşu açıklamada umut ve yaşamda anlamın rolü. Kastamonu Eğitim Dergisi, 20(3), 827-836.

Tarhan, S. ve Bacanli, S. (2015). Sürekli Umut Ölçeği'nin Türkçe’ye uyarlanması: Geçerlilik ve güvenilirlik çalışması.The Journal of Happiness \& Well-Being, 3(1), 1-14.

Telef, B. B. ve Ergün, E. (2013).Lise öğrencilerinin öznel iyi oluşlarının yordayıcısı olarak özyeterlik.Kuramsal Eğitimbilim Dergisi, 6(3), 423-433.

Ünal, A. Ö. ve Şahin, M. (2013).Lise öğrencilerinin yaşam doyumlarının bazı değişkenlere göre yordanması.Cumhuriyet International Journal of Education, 2(3), 46-63.

Valle, M. F., Huebner, E. S. ve Suldo, S. M. (2004). Further evaluation of the Children's Hope Scale.Journal of Psychoeducational Assessment, 22(4), 320-337. 